\title{
EFISIENSI PENGGUNAAN AIR PADA SISTEM MOBIL WUDHU
}

\author{
Mochammad Rizal ${ }^{1}$, Uung Ungkawa ${ }^{2}$, Marisa Premitasari ${ }^{3}$ \\ Program Studi Informatika, Fakultas Teknologi Industri \\ Institut Teknologi Nasional \\ Jl. PKH. Mustopha No.23, Neglasari, Cibeunying Kaler, Kota Bandung \\ rizalzulfikar215@gmail.com ${ }^{1}$, uung@itenas.ac.id ${ }^{2}$, marisa.premitasari@gmail.com ${ }^{3}$
}

\begin{abstract}
ABSTRAK
Wudhu merupakan kegiatan yang dilakukan setiap umat muslim ketika hendak melakukan kegiatan shalat. Mobil wudhu adalah suatu mobil yang terdapat saluran air yang diperuntukan untuk berwudhu ketika jumlah jamaah di suatu masjid membeludak atau terlalu banyak. Mobil air wudhu bisa menampung 4000 liter air. Proses berwudhu secara manual yang dilakukan memiliki kelemahan yaitu boros nya penggunaan air, Tujuan dari penelitian ini adalah untuk menghemat penggunaan air wudhu pada mobil wudhu. Metode Penelitian ini memodelkan sistem menggunakan sensor leap motion, Arduino Uno, sensor ultrasonic, dan kran air dengan motor servo. Sistem yang di buat menghasilkan output berupa keluar nya deras air menggunakan sensor leap motion untuk membuka kran air dengan motor servo sebagai pembuka kran deras air. Leap motion membaca pola tangan pada berupa data hasil pendeteksian tangan yang kemudian diproses oleh arduino untuk diteruskan ke web service dan diteruskan kembali untuk di proses di database. Pada penelitian ini di peroleh hasil dari pengujian yang dilakukan pada beberapa pengguna dengan kapasitas tangki air 3 liter dan menghasilkan rata rata penggunaan air 2,1 liter.
\end{abstract}

Kata kunci: Arduino, Leap Motion, Motor Servo, Mobil Wudhu, Sensor Ultrasonic.

\begin{abstract}
Wudu is an activity carried out by every Muslim when they want to perform prayer activities. The ablution car is a car with a water channel that is intended for ablution when the number of worshipers in a mosque is large or too large. The ablution water car can hold 4000 liters of water. The process of manual ablution which is carried out has a weakness, namely the wasteful use of water. The purpose of this study is to conserve the use of ablution water in the ablution car. This research method is to model the system using a leap motion sensor, Arduino Uno, ultrasonic sensor, and water faucet with a servo motor. The system that is made produces an output in the form of a rushing water using a leap motion sensor to open the water faucet with a servo motor to open a fast water faucet. Leap motion reads the hand pattern in the form of hand detection data which is then processed by Arduino to be forwarded to the web service and forwarded back to be processed in the database. In this study, the results obtained from tests carried out on several users with a water tank capacity of 3 liters and resulted in an average water usage of 2.1 liters.
\end{abstract}

Key Word : Arduino, Leap Motion, Motor Servo, Mobil Wudhu, Sensor Ultrasonic 


\section{PENDAHULUAN}

Berwudhu adalah cara untuk menghilangkan hadats, yakni hadats kecil. Wudhu biasanya dilakukan sebelum ibadah yang mengharuskan adanya kebersihan dan kesucian dari hadats kecil bagi yang akan melakukan ibadah tersebut, seperti contoh shalat. Perintah melaksanakan wudhu sebelum shalat terdapat dalam Surat AlMaidah ayat 6 . Kegiatan berwudhu juga banyak membutuhkan air untuk seorang muslim yang hendak sholat. Dan kegiatan berwudhu ini dilakukan sebanyak minimal 5 kali dalam sehari dengan rata-rata penggunaan setiap kali berwudhu menghabiskan 5 liter air.

Sering terjadinya penggunaan keran air ketika berwudhu secara sembarangan, terdapat ketika membuka kran air secara kasar, kemudian sering kali terdapat ketika menyelesaikan wudhu kran air tidak tertutup rapat atau lupa tidak menutupnya kembali. Mobil tangki air wudhu bisa menampung 4000 liter air. Mobil juga dilengkapi 12 keran di bagian samping kanan, kiri, dan belakang. Hitung-hitungan satu mobil tangki mobil bisa dipakai untuk 1333 orang lebih jamaah. Kalau menggunakan dengan cara wudhu yang benar, sekitar tiga liter per orang. (Untung 2016).

Truck tangki yang ditelah dimodifikasi menjadi sebuah mobil untuk berwudhu adalah sebuah inovasi dari petugas air kebersihan untuk membatu kepada para jamaah yang hendak berwudhu, ketika jumlah jamaah melebihi kapasitas masjid yang ada. Masalah pemborosan air sering kali terjadi karena kelalaian dalam menutup kran, kemudian membuka kran air sembarangan sehingga keluarnya air tidak dapat terkontrol dan menutup kran air tidak dengan rapat. Tujuan penelitian ini untuk merancang bangun sistem yang menghemat penggunaan air wudhu dan upaya pengawasan air wudhu.

Mobil tangki air wudhu bisa menampung 4000 liter air, mobil juga dilengkapi 12 keran di bagian samping kanan, kiri, dan belakang. Hitung-hitungan satu mobil tangki mobil bisa dipakai untuk 1333 orang lebih jamaah. Kalau menggunakan dengan cara wudhu yang benar, sekitar tiga liter per orang. (Untung 2016). Berdasarkan rumusan masalah penelitian tersebut yang diajukan antara lain:

1. Bagaimana menghemat penggunaan air untuk berwudhu.
2. Bagaimana membangun sistem kran berdasarkan pola tangan gerakan berwudhu.

Tujuan penelitian ini untuk merancang bangun sistem yang menghemat penggunaan air wudhu dan upaya pengawasan air wudhu.

Untuk memperjelas masalah yang akan dibahas pada penelitian ini dan tidak terjadi pembahasan yang meluas atau menyimpang, maka perlu kiranya dibuat suatu batasan masalah yaitu sebagai berikut :

1. Air wudhu menggunakan mobil wudhu.

2. Keran air menggunakan motor servo.

3. Diasumsikan tangki air berbentuk lingkaran dengan kapasitas 5 liter.

4. Madzhab yang diterapkan adalah madzhab As-Syafi'i

5. Gerakan wudhu sebanyak 3 kali masingmasing gerakan

6. Gerakan kaki dengan cara menampung dulu air pada tangan.

\section{LANDASAN TEORI}

\section{II.1 Leap Motion}

Leap Motion Controller adalah alat sensor perangkat keras komputer yang mendukung gerakan tangan dan jari sebagai masukan, yang dapat disamakan fungsinya seperti mouse, namun tidak membutuhkan kontak langsung dengan tangan atau sentuhan (Yowanda, et al. 2014). Leap Motion Controller terkadang juga disingkat menjadi Leap Motion. Namun, pengertian Leap Motion dapat juga berarti perusahaan Leap Motion yang mengeluarkan Leap Motion Controller. Maka dari itu alat yang berupa sensor gerak tangan ini seterusnya akan disebut dengan Leap Motion Controller seperti pada Gambar 1.

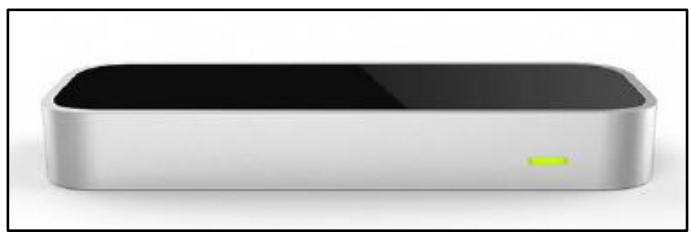

Gambar 1. leap motion controller

\section{II.2 Wudhu}

Di dalam kamus bahasa arab "al Wudhu" dengan dhommah, berarti pekerjaan bersuci dan dengan huruf wawunya (Wadhu), berarti air yang dipergunakan untuk berwudhu. (Abubakar 
Muhammad, Al Ikhlas, 1998). Wudhu menurut bahasa artinya bersih dan indah, sedang menurut syara' artinya membersihkan anggota wudhu untuk menghilangkan hadats kecil. (Moh. Rifa'I, 2015).

Al Imam Ibnu Atsir Al-Jazary rohimahumullah (seorang ahli bahasa) menjelaskan bahwa jika dikatakan wadhu' (الوضوء), maka yang dimaksud adalah air yang digunakan berwudhu. Bila dikatakan wudhu (الوضوء), maka yang diinginkan di situ adalah perbuatannya. Jadi, wudhu adalah perbuatan sedang wadhu adalah air wudhu. (Muhammad bin Sholih Al-Utsaimin, Jannatul Afkar, 2008). Al-Hafizh Ibnu Hajar Asy-Syafi'iy rohimahulloh, kata wudhu terambil dari kata alwadho'ah / kesucian (الوضوء). Wudhu disebut demikian, karena orang yang sholat membersihkan diri dengannya. Akhirnya, ia menjadi orang yang suci. (Pustaka Azam, 2001).

\section{II.3 Tangki Air}

Tangki air adalah wadah bagi air, tangki air pastinya tak bisa lepas dari yang namanya air, Tangki air banyak digunakan sebagai penampungan air. Model tangki air ini berbentuk tabung dengan tapasitas tangki penampungan air sebanyak 5 liter dengan ukuran dimensi tangki adalah panjang $33 \mathrm{~cm}$, diameter $14 \mathrm{~cm}$, dan tinggi $9,97 \mathrm{~cm}$.

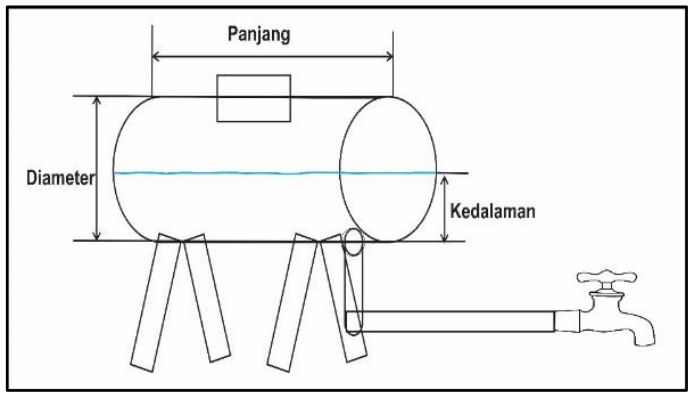

Gambar 2. Tangki Air

\section{METODOLOGI PENELITIAN}

\section{III.1 Perancangan Sistem}

Sistem ini dibangun menggunakan metode penelitian prototype yang digunakan sebagai cara untuk melakukan proses penelitian dengan tahapan yang akan dilakukan pada penelitian ini yaitu melakukan perancangan sistem yang meliputi kebutuhan hardware yang akan digunakan dalam pembangunan sistem, melakukan pengemasan sistem seperti pemasangan dan perangkaian semua komponen hardware utama seperti arduino sebagai mikrokontroler (pengendali rangkaian), sensor leap motion mendeteksi adanya objek tangan yang dekat dengan kran wudhu. Kemudian arduino akan mengirimkan arus pada driver motor servo untuk menjalankan air secara otomatis. Jika pengguna akan berpindah anggota wudhu maka sensor akan mendeteksi berdasarkan gerakan tangan, pada proses perpindahan anggota wudhu volume air akan ikut mengecil begitu seterusnya, sensor ultrasonic sebagai pembaca level air pada tangki mobil, module ethernet shield digunakan untuk mengkoneksikan arduino dengan web service dan database sistem, motor servo sebagai pembuka keran air, proses pengklasifikasian untuk melakukan penyesuaian pola tangan sebagai inputan. Penyesuaian tersebut akan menghasilkan output termasuk dalam deras keluarnya air yang kemudian data dikirimkan ke motor servo berupa output derasnya air. Perancangan umum untuk efisiensi penggunaan air pada sistem mobil wudhu adalah sebagai berikut :

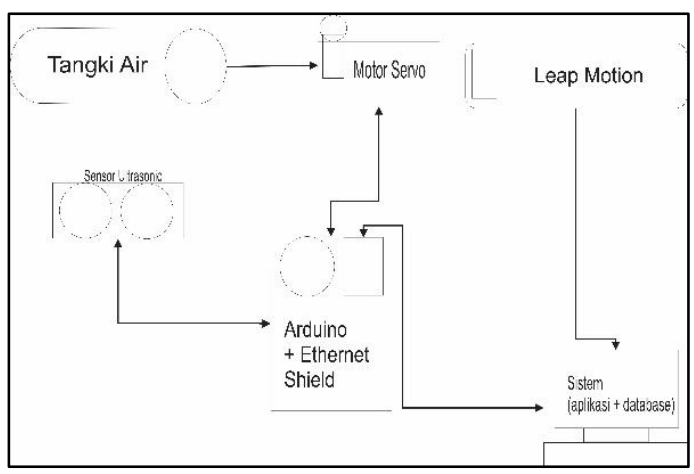

Gambar 3. Quick Design

Dari skema quick design diatas sistem secara keseluruhan terbagi atas dua bagian yaitu hardware dan software, sesuai dengan penomoran pada gambar penjelasan secara singkat nya adalah sebagai berikut :

1. Digambarkan pada sistem terdapat aplikasi yang terhubung ke database, secara singkat aplikasi dibuat untuk proses pendeteksian pola tangan, dimana data pola tangan bisa dilihat pada aplikasi. Aplikasi dibuat menggunakan Netbeans, Sublime, HeidiSQL.

2. Terdiri atas komponen-komponen hardware yang digunakan pada penelitian ini, Semua komponen hardware dirakit dengan cara dihubungkan ke arduino sebagai mikrokontroler melalui pin generik (GPIO) sehingga terbentuk menjadi suatu sistem. 
Listing program untuk tiap-tiap komponen dilakukan pada software arduino IDE.

Berikut ini adalah blok diagram dari sistem efisiensi penggunaan air pada sistem mobil wudhu:

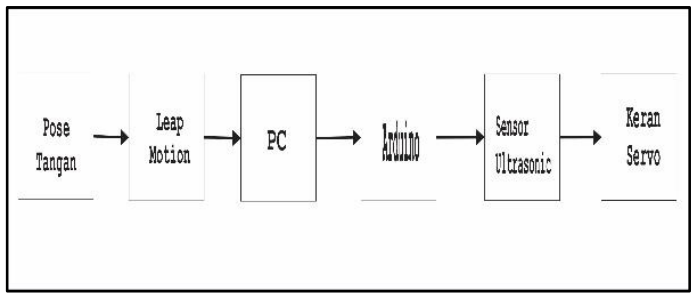

Gambar 4 Blok Diagram

Dari Gambar 4 Mengenai proses sistem keseluruhan dilakukan dengan tahapan sebagai berikut :

1. Pola tangan sebagai input yang akan dibaca oleh sensor leap motion.

2. Sensor leap motion digunakan untuk melakukan proses pembacaan pola tangan yang akan digunakan dalam pendeteksian pola tangan.

3. PC atau laptop digunakan untuk melakukan proses pengklasifikasian pola tangan yang telah terhubung dengan sensor leap motion lalu diterjemahkan menjadi sebuah data hasil nilai $\mathrm{x}$.

4. Arduino atau mikrokontroller akan memberikan instruksi kepada sensor ultrasonic dan motor servo.

5. Sensor ultrasonic berfungsi untuk melakukan pengecekan isi air pada tangki atau membaca jumlah air yang tersisa pada tangki air.

6. Motor servo sebagai kontrol kran mendapat perintah dari mikrokontroller untuk bergerak yang akan menggerakkan kran air.

\section{III.2 Alur sistem kran wudhu otomatis}

Terdapat 3 buah flowchart pada bagian ini, di mana flowchart pertama menjelaskan mengenai proses sistem kerja, kemudian membaca pola tangan untuk menentukan deras air yang keluar, dan flowchart ketiga mengenai pembacaan level air pada tangki.

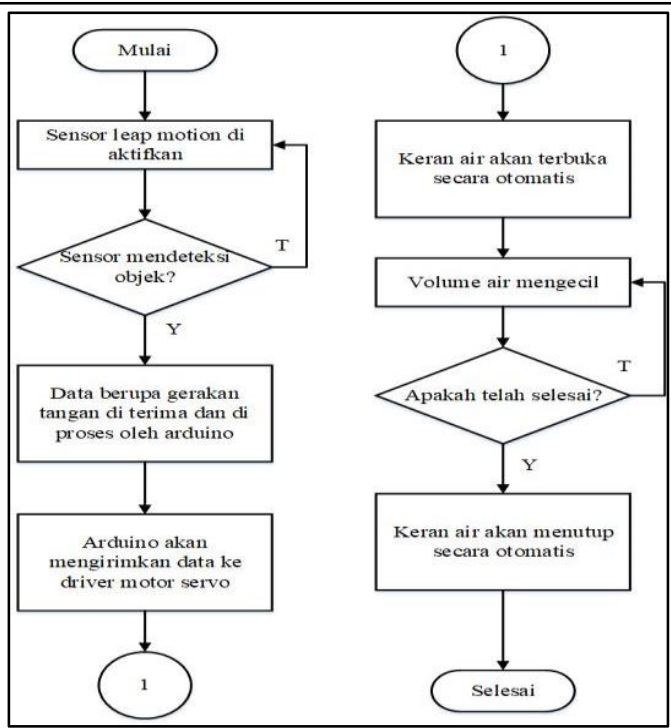

Gambar 5 Flowchart sistem

Berdasarkan pada flowchart sistem pada Gambar 5 terdapat tahapan-tahapan pada saat proses pengambilan air wudhu dilakukan, yaitu :

1. Tahapan pertama dimulai pada saat sensor leap motion di aktifkan.

2. Sensor akan mendetaksi adanya objek yang hendak berwudhu. Dengan cara mendekatkan objek tangan ke sensor leap motion tersebut.

3. Sensor leap motion yang membaca objek gerakan pola tangan dengan cara data berupa gerakan cara kerja alat tersebut diawali dengan komunikasi antara perangkat lunak Leap Service yang telah terpasang di komputer dengan perangkat keras Leap Motion Controller melalui port USB. Tangan akan di deteksi dengan perangkat keras Leap Motion Controller lalu data tangan yang telah di deteksi di olah dalam Leap Service. Lalu Leap Service menyampaikan data penjejakan tangan tersebut kepada aplikasi Leap-enabled. Aplikasi Leap-enabled inilah yang nantinya digunakan untuk memvisualisasikan data penjejakan tangan. Selain itu, terdapat Leap Settings App yang digunakan untuk menentukan konfigurasi Leap Motion Controller.

4. Maka arduino akan mengirimkan data pada motor servo untuk air secara otomatis. Jika pengguna akan berpindah anggota wudhu maka sensor akan mendeteksi.

5. Keran air akan membuka secara otomatis 
6. Volume air mengecil berdasarkan jarak, pada proses perpindahan anggota wudhu volume air akan ikut mengecil begitu seterusnya.

7. Keran air akan menutup secara otomatis Setelah objek sudah tidak mendeteksi keberadaan objek maka keran akan otomatis akan menutup dengan sendirinya.

Pada sistem ini digunakan mikrokontroller berupa arduino uno R3 berfungsi sebagai sistem minimum perangkat yang digunakan sebagai otak utama dari sistem yang dijalankan. Adapun spesifikasi pin yang digunakan dalam perancangan sistem ini akan dipaparkan sebagai berikut dalam berikut :

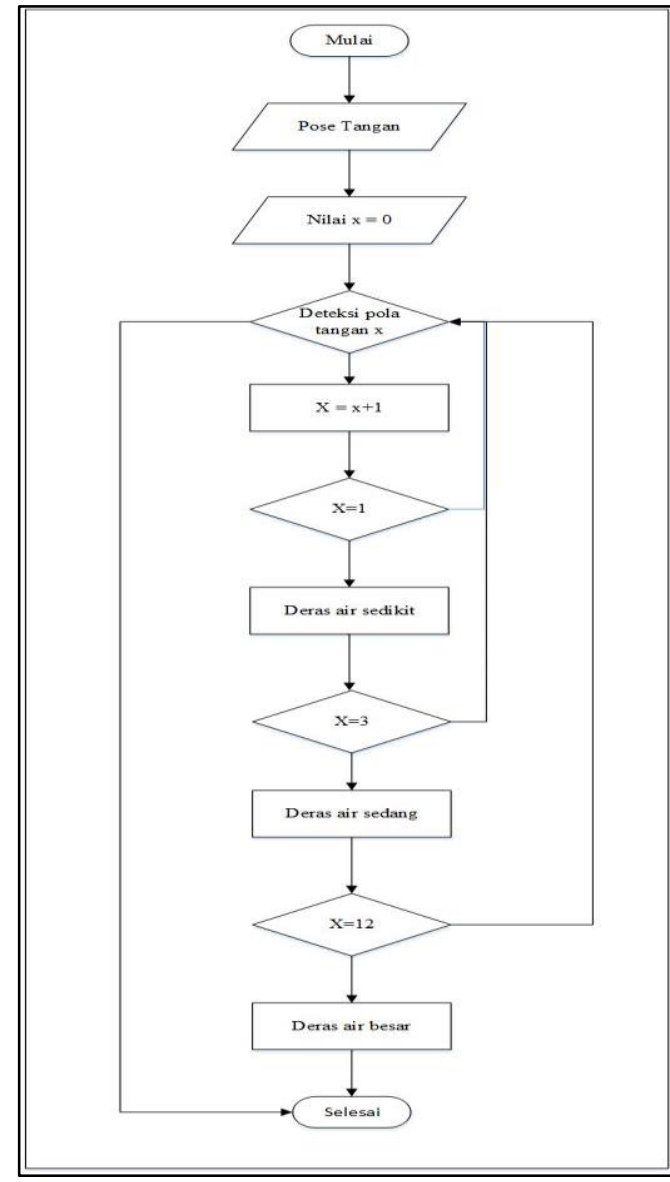

Gambar 6 Flowchart sistem membaca pola tangan.

Berdasarkan pada flowchart sistem pembaca pola tangan pada Gambar 6. Terdapat tahapan pada saat proses pembacaan pola tangan sebagai penentu deras kran air dilakukan, yaitu :

1. Pembacaan pola tangan oleh sensor leap motion.
2. Data pola tangan dibaca dengan nilai awal adalah $\mathrm{x}=0$ pada variabel pola tangan yang dideteksi.

3. Pendeteksian pola tangan dengan cara mencari nilai terdekat pada hasil objek yang telah dibaca oleh sensor leap motion, data hasil pada sensor leap motion terdapat 4 nilai data, hasil data nilai tergantung dari pola tangan, yang pertama pola mengepal, kedua pola seperempat mengepal, ketiga pola setengah menepal, dan yang terakhir yang ke empat pola membuka kepalan secara penuh nilai awal adalah $\mathrm{x}=0$, pendeteksian ini dilakukan dengan cara tangan didekatkan ke alat sensor leap motion.

4. Setelah didapat variabel pola tangan yang, maka nilai $\mathrm{x}=0$ akan ditambahkan 1 .

5. Jika nilai $x=1$ maka kran dengan deras air kecil.

6. Setelah nilai $\mathrm{x}=1$ dan akan seterusnya ditambahkan setiap terbacanya pola tangan.

7. Jika nilai $\mathrm{x}=3$ maka kran dengan deras air sedang.

8. Apabila deketsi tangan telah mencapai batas yang ditentukan adalah jika nilai $\mathrm{x}=12$ maka kran dengan deras air besar.

\section{III.3 Perancangan interkoneksi hardware}

Tahapan perancangan prototype, yaitu perancangan komponen hardware, setelah tahapan perancangan dilakukan perakitan sampai semuanya terkoneksi menjadi satu kesatuan sistem. Semua komponen hadware dirakit dan dikoneksikan ke module arduino uno sebagai mikrokontroller dari sistem ini, dimana gambaran rancangan interkoneksi hardware dapat dilihat pada Gambar 7 Prototype. 


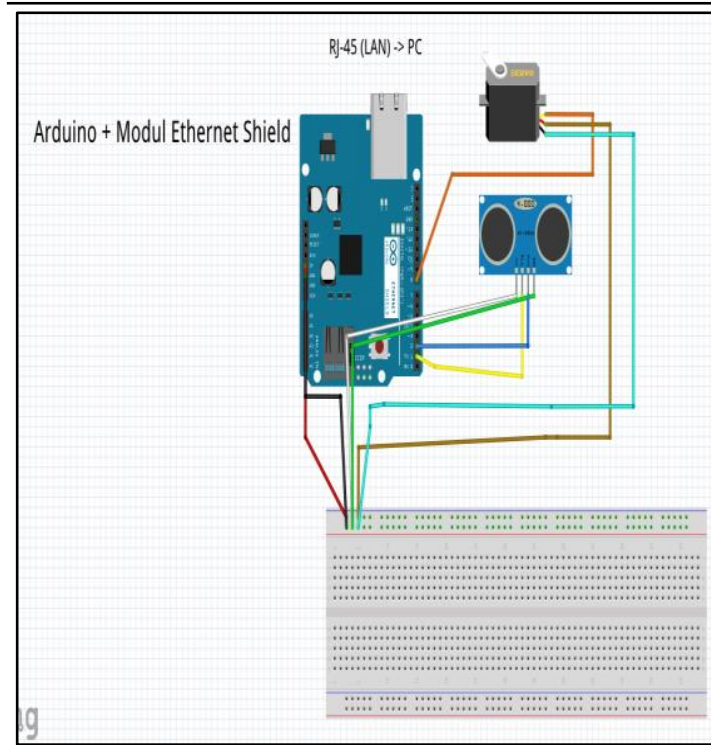

Gambar 7 Interkoneksi hardware

\section{HASIL DAN PEMBAHASAN}

Pengujian dilakukan untuk menggetahui apakah setiap komponen dari sistem berfungsi sesuai dengan yang diharapkan.

Untuk mengetahui kinerja sistem, maka diperlukan untuk dilakukannya pengujian. Pengujian yang diterapkan pada sistem penelitian efisiensi penggunaan air pada mobil wudhu yaitu dengan cara menguji secara fungsionalitas terhadap beberapa komponen dan fungsi yang ada serta pengujian keseluruhan sistem.
Tabel 1 Pengujian Fungsional

\begin{tabular}{|c|c|c|c|c|}
\hline No & $\begin{array}{l}\text { Komponen } \\
\text { yang } \\
\text { di uji }\end{array}$ & Pengujian & $\begin{array}{c}\text { Status/ } \\
\text { parameter }\end{array}$ & Keterangan \\
\hline 1 & $\begin{array}{c}\text { Modul arduino } \\
\text { uno }\end{array}$ & $\begin{array}{l}\text { Melakukan listing } \\
\text { program }\end{array}$ & Berhasil & $\begin{array}{l}\text { Komponen lain } \\
\text { berfungsi sesuai } \\
\text { dengan perintah } \\
\text { program dari } \\
\text { mikrokontroller } \\
\text { arduino. }\end{array}$ \\
\hline 2 & $\begin{array}{l}\text { Module Ethernet } \\
\text { Shield }\end{array}$ & $\begin{array}{l}\text { Menghubungkan } \\
\text { Arduino dengan } \\
\text { PC (System) }\end{array}$ & Berhasil & $\begin{array}{l}\text { Module arduino uno } \\
\text { berhasil terkoneksi ke } \\
\text { PC (System), melalui } \\
\text { jalur komunikasi LAN } \\
\text { yang terhubung ke } \\
\text { ethernet shield }\end{array}$ \\
\hline 3 & $\begin{array}{l}\text { Sensor } \\
\text { Ultrasonic }\end{array}$ & $\begin{array}{l}\text { Melakukan } \\
\text { pembacaan jarak }\end{array}$ & Berhasil & $\begin{array}{l}\text { Modul sensor } \\
\text { ultrasonic berhasil } \\
\text { membaca jarak dan } \\
\text { pada objek. }\end{array}$ \\
\hline 4 & Motor Servo & $\begin{array}{l}\text { Melakukan } \\
\text { putaran } 180^{\circ}, \\
90^{\circ}, 0^{\circ}\end{array}$ & Berhasil & $\begin{array}{l}\text { Ketika leap motion } \\
\text { yang berhasil dibaca, } \\
\text { motor servo langsung } \\
\text { berputar. Dan ketika } \\
\text { leap motion tidak } \\
\end{array}$ \\
\hline 5 & Leap Motion & $\begin{array}{l}\text { Melaukan } \\
\text { pendekteksian } \\
\text { objek tangan }\end{array}$ & Berhasil & \begin{tabular}{|l|} 
Leap motion \\
terkoneksi dengan pc \\
dan mendeteksi objek \\
tangan.
\end{tabular} \\
\hline
\end{tabular}

Terdapat juga tabel dari pengujian dari sensor ultrasonic untuk mngetahui seberapa akurat sensor ultrasonic tersebut dalam mengukur jarak suatu benda.

Tabel 2 pengujian sensor ultrasonic

\begin{tabular}{|c|c|c|c|}
\hline No & $\begin{array}{c}\text { Jarak terhadap } \\
\text { dinding (cm) }\end{array}$ & $\begin{array}{c}\text { Data Sensor } \\
\text { ultrasonic } \mathbf{( c m )}\end{array}$ & Selisih Nilai \\
\hline 1 & 3 & 3 & 0 \\
\hline 2 & 4 & 4 & 0 \\
\hline 3 & 5 & 4 & 0 \\
\hline 4 & 6 & 6 & 0 \\
\hline 5 & 7 & 7 & 0 \\
\hline 6 & 8 & 8 & 0 \\
\hline 7 & 9 & 9 & 0 \\
\hline 8 & 10 & 10 & 0 \\
\hline 9 & 11 & 10 & 1 \\
\hline 10 & 12 & 12 & 0 \\
\hline 11 & 13 & 13 & 0 \\
\hline 12 & 14 & 14 & 0 \\
\hline 13 & 15 & 16 & 0 \\
\hline 14 & 16 & 16 & 0 \\
\hline 15 & 17 & 17 & 0 \\
\hline 16 & 18 & 18 & 0 \\
\hline 17 & 19 & 19 & 1 \\
\hline 18 & 20 & 21 & 1 \\
\hline 19 & 21 & 22 & \\
\hline 20 & 22 & & 0 \\
\hline & & 23 & 0 \\
\hline
\end{tabular}


Tangki air berfungsi untuk menampung air sekitar 5 liter, tangki ini akan menjadi sumber air yang akan digunakan ketika berwudhu. Tangki air juga sudah terhubung dengan pipa agar dapat tersambung dengan kran air. Sebelum melakukan pengujian terlebih dahulu air dimasukan kedalam tangki sebanyak 3 liter, kemudian dilakukan pengambilan wudhu sebanyak 10 setiap satu kali berwudhu jumlah air dalam tangki akan dikeluarkan hingga habis dan ditampung oleh gelas ukur. Untuk mengetahui banyak air yang dihabiskan oleh peserta, dapat dihitung dengan cara mengeluarkan semua air yang ada pada tangki dan titampung oleh gelas ukur kemudian dihitung berapa liter air yang tersisa.

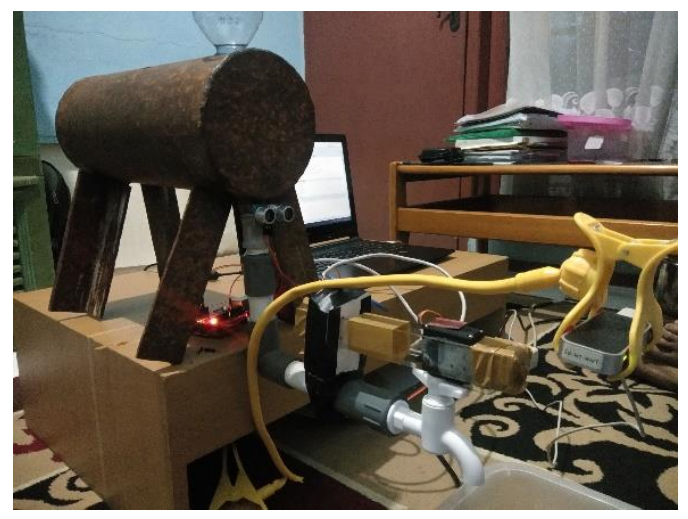

Gambar 8 Rangkaian Alat

Adapun cara untuk mengetahui berapa banyak air yang dihabiskan saat mengambil wudhu, dapat diketahui dengan cara menghitung jumlah sisa air yang ada pada tangki.

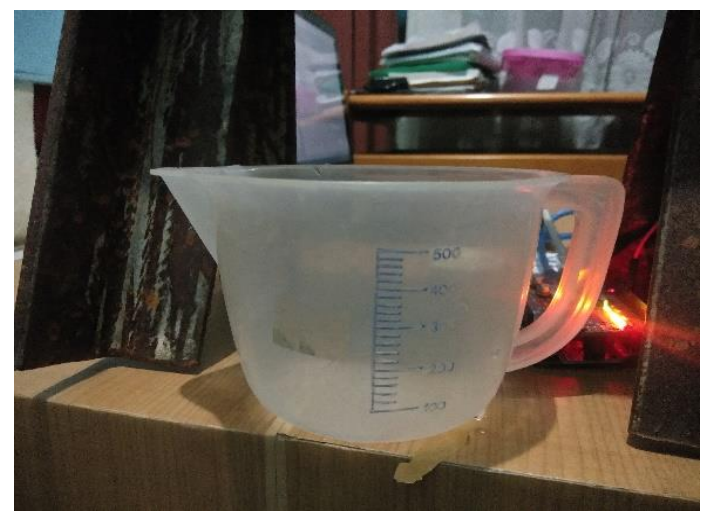

Gambar 9 Gelas ukur dengan kapasitas 500 ml

Gelas ukur tersebut berfungsi untuk menambahkan air kedalam tangki, menggunakan gelas ukur agar mengetahui jumlah air yang di masukan ke dalam tangki air.
Pengujian bertujuan untuk mengetahui berapa liter yang dihabiskan oleh seseorang dalam mengambil wudhu. Pengujian ini dilakukan dengan cara menguji coba alat langsung ke orang. Dalam pengujiannya hanya dilakukan sebanyak 5 orang. Dari pengujian ini akan dilihat berapa liter air yang dihabiskan dalam mengambil wudhu. Adapun untuk mengetahui berapa banyak air yang dihabiskan saat mengambil wudhu, dapat diketahui dengan cara menghitung jumlah sisa air yang ada pada tanki.

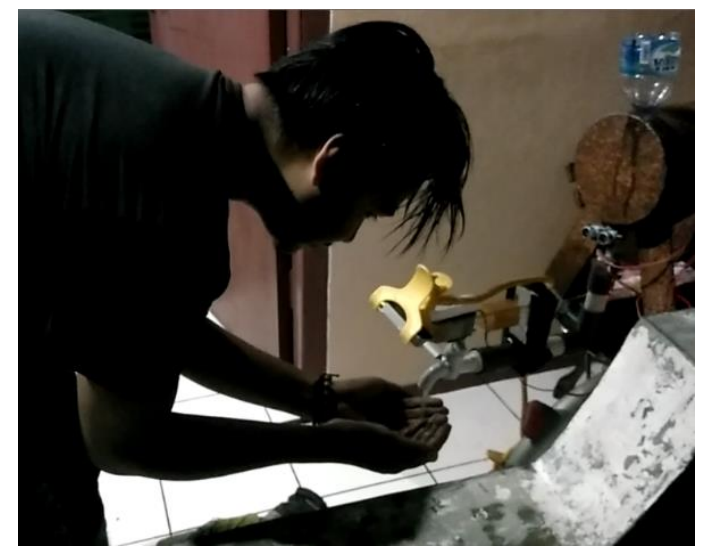

Gambar 10 Pengujian wudhu

Tabel 3 Pengujian berwudhu

\begin{tabular}{|c|l|l|l|l|}
\hline Jumlah Pengujan & Nama & Target Wudhu & Konvensional & Otomatis \\
\hline 1 & Rizki Lukman & 3 Liter & 4 Liter & 1,8 Liter \\
\hline 2 & Yudi Widiawan & 3 Liter & 4,5 Liter & 2,3 Liter \\
\hline 3 & Khalifah Falah & 3 Liter & 4 Liter & 2 Liter \\
\hline 4 & Dixy Abdul & 3 Liter & 5 Liter & 3 Liter \\
\hline 5 & Moch Febri & 3 Liter & 4,5 Liter & 2,4 Liter \\
\hline Rata-rata & \multicolumn{4}{|c|}{ 2,1 Liter } \\
\hline Selisih & \multicolumn{4}{|c}{} \\
\hline
\end{tabular}




\section{KESIMPULAN}

Dari hasil penelitian rancang bangun keran wudhu hemat air ini dapat diambil kesimpulan yaitu Perakitan alat wudhu otomatis telah berhasil dirancang, pengujian alat dibuktikan dengan beberapa kali eksperimen, hasil pengujian yang didapat kran motor servo akan aktif jika terbaca pola tangan sesuai gerakan wudhu dan akan mati gerakan wudhu sudah melebihi batas yang ditentukan. Hasil dari rata-rata penggunaan air wudhu adalah sebanyak 2,3 liter dan didapatkan selisih penghematan air sekitar 2,1 Liter.

\section{REFERENSI}

Romi Wijaya (2015), Aplikasi Mikrokontroler Pada Sistem Kran air Wudhu Otomatis Dengan Tampilan LCD ( Liquid Crystal Display) Dan Output Suara Yang Diimplementasikan Pada Mesjid Atau Mushalla pada Universitas Putra Indonesia YPTK Padang, Indonesia.

Sutris Astari, Rozeff Pramana.ST.,MT, Deny Nusyirwan.,Msc (2015), Kran Air Wudhu' Otomatis Berbasis Arduino Atmega 328 pada Fakultas Teknik Universitas Maritim Raja Ali Haji.

Jufrizel, Muhmammad Zakir (2015), Perancangan Prototype Kran Wudhu Otomatis Berbasis Arduino Uno untuk Menghemat Air Menggunakan Sensor Ping pada Teknik Elektro, Fakultas Sains dan Teknologi, UIN Sultan Syarif Kasim Riau.

Budi Eko Sulistiyono, Hugo Aprilianto, Panca Anitasari W.H (2015), Rancang Bangun Kran Air Wudhu Otomatis Dan Kontrol Bak Air Berbasis Arduino pada Program Studi Teknik Informatika, STMIK Banjarbaru.

Agustiawan, Abdul Hadi (2017), Efisiensi Rancang Bangun Keran Wudhu Otomatis Hemat Air pada Teknologi Informasi, Komunikasi dan Industri (SNTIKI) Fakultas Sains dan Teknologi, UIN Sultan Syarif Kasim Riau Pekanbaru.
Jufrizel,MT, Weni Puji Hastuti, M.KP (2017)

Manfaat Pembuatan Perencanaan Kran Wudhu Otomatis Bagi Kemaslahatan Umat Islam pada Teknologi Informasi, Komunikasi dan Industri (SNTIKI) Fakultas Sains dan Teknologi, UIN Sultan Syarif Kasim Riau Pekanbaru.

Moh. Vita Nur Adhitya dkk (2015) Perancangan dan Realisasi Keran dan Pengisian Tangki Air Otomatis dengan Sensor Ultrasonik dan Liquid Water Level Menggunakan at-mega 328 pada Prodi D3Teknik Telekomunikasi, Fakultas Teknik Elektro, Universitas Telkom

Rausan Fikri Dkk, (2015) Rancang Bangun Sistem Monitoring Ketinggian Permukaan Air Menggunakan Mikrokontroler. ATMEGA328P Berbasis Web Service pada Program Studi Fisika Fakultas Matematika Dan Ilmu Pengetahuan Alam Universitas Tanjungpura Pontianak, Indonesia.

Achmad Basuki Dkk (2016), Sensor Gerak Dengan Leap Motion Untuk Membantu Komunikasi Tuna Rungu/Wicara pada Program Studi Teknik Informatika Politeknik Elektronika Negeri Surabaya

Andyan Bina Ardhana Dkk (2018), Sistem Kendali Navigasi Ar Drone Menggunakan Leap Motion pada Program Studi Teknik Informatika, Fakultas Ilmu Komputer, Universitas Brawijaya. 